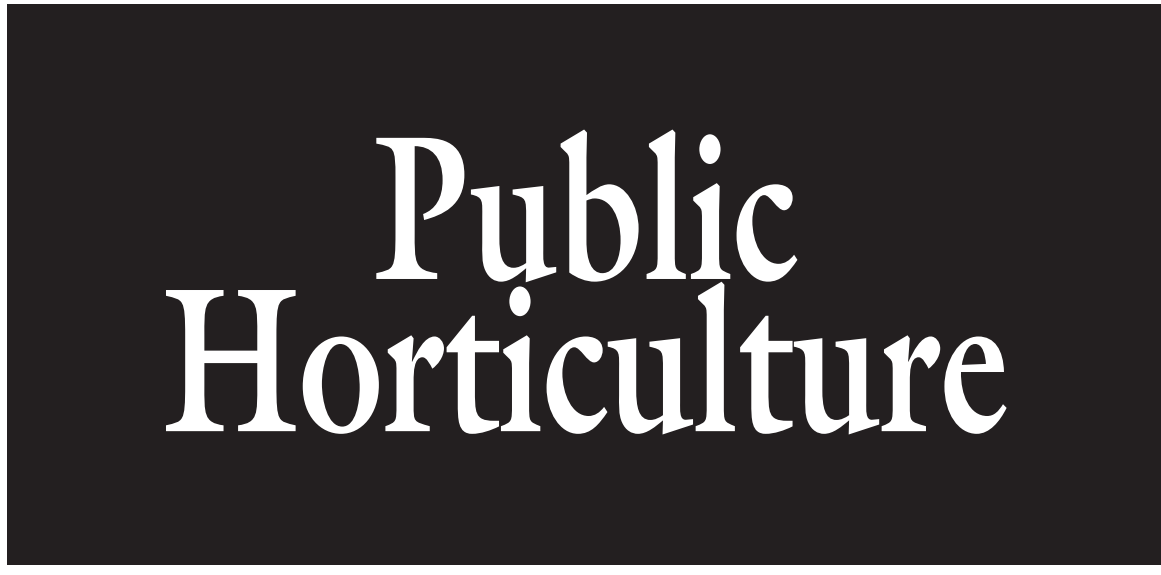

\title{
Exotic Plant Inventory, Landscape Survey, and Invasiveness Assessment: Roosevelt-Vanderbilt National Historic Sites, Hyde Park, NY
}

\author{
Melissa Bravo ${ }^{1,5,6}$, Antonio DiTommaso ${ }^{2,3}$, and David Hayes ${ }^{1,4}$
}

ADDITIONAL INDEX WORDS. ornamental, garden forb, crop, weed, aquatic, cultural landscape reports, invasive species management plan

Summary. An exotic plant cultural landscape inventory, area wide survey, and natural resource area invasiveness assessment was conducted in 2002 at the Roosevelt-Vanderbilt (ROVA) National Historic Sites (NHS) in Hyde Park, NY. At the species level, $40 \%$ of 90 assessed landscape species had not escaped cultivation, $44 \%$ had escaped and invaded natural resource areas, and $16 \%$ were categorized as migratory invaders. The most prolific introduced woody trees and vines at ROVA are members of the trumpetvine, bittersweet, pea, buckthorn, quassia, and grape families (Bignoniaceae, Celastraceae, Fabaceae, Rhamnaceae, Simaroubaceae, and Vitaceae, respectively). Shrub species occurring with more frequency in the natural areas than other escapes are the introduced native atlantic nine bark (Physocarpus opulifolius), burning bush (Euonymus alatus), forsythia (Forsythia sp.), japanese barberry (Berberis thunbergii), morrow's honeysuckle (Lonicera morrowii), tatarian honeysuckle (Lonicera tatarica), and mock orange (Philadelphussp.). For the subset of assessed woody vines, shrubs, and tree species found in cultivation for at least $\mathbf{5 0}$ to 67 years (the "50 plus club species"), slightly more had escaped from cultivation for the Vanderbilt Mansion (VAMA) and Eleanor Roosevelt (ELRO) estates but for the Franklin Delano Roosevelt (FDR) collection the numbers were equivalent. The approach used in this study illustrates with data the "movement" of exotics over a significant period of time and underscores the importance of site-specific and species-specific assessments. This assessment also emphasizes the value of understanding the history (e.g., cultivated, cultivated escaped, or migratory invaders), purpose (e.g., aquatic, crop garden forb, groundcover, ornamental, or weed), and management over time (e.g., long since abandoned, recently abandoned, or still maintained, etc.) of the geographic area under consideration and the use of available exotic invasive plant lists to conduct such assessments.

$\mathrm{T}$ The ROVA NHS is a complex of six parcels located in the town of Hyde Park in the Hudson River Valley of New York State. The VAMA is situated (lat. $41.79^{\circ} \mathrm{N}$, long. $73.90^{\circ} \mathrm{W}$ ) on a plateau overlooking the Hudson River and has a unique land feature (Bard Rock) that juts into the Hudson River. The Home of FDR is 2 miles farther south and includes three properties: the Bellefield estate, the FDR mansion, and the Springwood Viewshed parcel. The VAMA and FDR estates are fronted by Route 9, connected by the Hyde Park Trail, and paralleled by the Hudson River Rail line and the Hudson River. The Home of ELRO and FDR's retreat
(Top Cottage) are farther inland (lat. $41.76^{\circ} \mathrm{N}$, long. $73.90^{\circ} \mathrm{W}$ ) on Route 9G, 2 miles east of FDR. All together these sites total about 800 acres. The historical mansions and outbuildings of these estates are surrounded by cultivated areas (manicured lawns, flowerbeds, formal flower gardens, and cropland including conifer plantations) as well as naturally occurring, uncultivated areas described in the various ecological reports reviewed as fallowed crop fields, actively eroding gullies, northern red (Quercus borealis)/chestnut oak (Quercus prinus) communities, oak (Quercus sp.)/tulip poplar (Liriodendron tulipifera) communities, miscellaneous hardwood/ hemlock (Tsuga sp.) communities, and freshwater intertidal mudflats. Each site has a rich history of introduced exotic plant species in the manicured landscape and exotic crops for agricultural and silvicultural purposes.

\section{History of purposeful introduction}

Exotic plants were introduced into the landscape of VAMA as early as 1764 when Samuel Bard built the first mansion (Claeys and Coffin, 1995; Glenn, 1998; O’Donnell et al., 1992; Favretti and Rainey, 1988; Rudnicky, 1984). Introductions have occurred since 1881 at the FDR estate (Baker and Curray, 1999; Claeys and Coffin, 1995; Dutton, 1998) and at least since 1926 at the ELRO estate (Claeys and Coffin, 1995; Dutton, 1998; Kane and Carruth, 1981) and presumably earlier given the European colonization of this area of New York in the 1600s. The management of these private homes/parcels was assumed by the National Park Service (NPS) in 1940 at which time additional plantings occurred. The historical interpretive period maintained by the Park Service for VAMA is $1900-38$, for FDR is $1941-45$, and for ELRO is 1960-62. The cultivated vegetation associated with these interpretive time periods includes a significant number of exotic species and they are an integral component of the preservation for these NHS. By reviewing hundreds of historical archived photographs and historical planting records, a range for the decade of introduction of specific exotics throughout ROVA was determined and if noted, the exact year the species was planted. 


\section{Method and materials}

Study site. An exotic plant inventory of the cultural landscape plantings followed by an exotic plant survey of all areas of the estates and an invasive exotic plant assessment of the natural resource areas were conducted in the Summer 2002. At the time, the NPS flora list (Hayes, 1992) for ROVA contained 380 species (native and exotic) known from the cultural landscape and natural areas including herbarium specimens. Because of the volunteer management of the public flower gardens (i.e., no formal recordkeeping from year to year), the thousands of annual and perennial forbs (garden forbs) in these formal gardens were excluded from this study unless they were referenced in the early garden plans (1903 and 1910) and subsequently also found in the flora list, herbarium, or cultural landscape reports (CLRs; years 1981 to 2002 ). The VAMA Italian garden flora introductions date back to the Bard ownership in 1795, the Hosack and Langdon ownership beginning in 1830, and the Vanderbilt ownership beginning in 1902-03.

Leslie Mehrhoff, a former researcher in the Department of Ecology and Evolutionary Biology and former curator of the George Safford Torrey Herbarium, University of Connecticut was awarded the U.S Environmental Protection Agency's highest honor in May 2011 earning a Lifetime Achievement Award for his contributions to understanding plant biodiversity. A fund entitled "Leslie J. Mehrhoff, PhD Conservation and Biodiversity Fund" has been established in his honor at the University of Connecticut. A pledge form is available from The University of Connecticut Foundation Inc., ATTN: Annual Giving. 2390 Alumni Drive, Unit 3206. Storrs, CT 06269-3206.

The lead author thanks the late Leslie Mehrhoff, curator of the University of Connecticut George Safford Torrey Herbarium, for his enthusiastic assistance and publications that were essential in identifying closely related species (University of Connecticut, 2010); Ann Rhoads and Tim Block of the Morris Arboretum for their timely publication (2000) of the Flora of Pennsylvania and William S. Curran, Professor of Weed Science at The Pennsylvania State University who sparked the lead author's interest in invasive species during her Master's Degree program in Weed Science in the Department of Crop and Soil Sciences.

${ }^{1}$ Department of Natural Resources, Roosevelt-Vanderbilt National Historic Sites, 4097 Albany Post Road, Hyde Park, NY 12538

${ }^{2}$ Department of Crop and Soil Sciences, Cornell University, Ithaca, NY 14853

${ }^{3}$ Associate Professor

${ }^{4}$ Biologist, Natural Resource Manager

${ }^{5}$ Current address: Invasive Species Specialist, Meadow Lake Farm Consulting Services, 2810 Bliss Road, P.O. Box 447, Lawrenceville, PA 16929

${ }^{6}$ Corresponding author. E-mail: bravomelissa@yahoo. com.
CulTuRAL LANDSCAPE INVENTORY CLRs, formal garden plans, forest ecology studies (e.g., Auwaerter, 2009; Kane and Carruth, 1981; O'Donnell et al., 1992; Favretti and Rainey, 1988), and herbarium specimens (Hayes, 1992, 2002; ROVA NHS, 2002) were reviewed 1) to establish the relevance of the species to the "historical preservation time periods" for each estate for specific exotic introductions and 2 ) to find the location of plantings in the cultivated landscape for these NHS.

Exotic Plant SURvey. Field investigations of the 800 -acre complex occurred from 14 May to 29 July 2002 and as necessary to complete the project through the end of Sept. 2002. Plant species that were targeted in the survey were identified from a review of the historical records, the cultural landscape inventory, and two invasive plant lists available at the time depicting 120 exotic plants as "known or potential invaders" of natural areas. The available invasive exotic plant lists were from the NPS (2002) and the Mid-Atlantic Exotic Plant Pest Council (MAEPPC, 2002). Six introduced native species (Mitchell, 1986; New York Flora Association, 1990) that are key species in the preservation time periods for these estates were also included in the survey and assessment. It is important to note, at the time of this study in 2002, New York State did not have a publicly available invasive plant list. However, since then a ranking system for evaluating nonnative plant species for invasiveness in New York has been developed and relevant information included in this report (Jordan et al., 2010).

SURVEY METHODOLOGY. The survey methodology was similar to that used in other invasive plant investigations (e.g., Dewey and Anderson, 2004) and typical weed monitoring/ ranking methods used in agricultural crop management in Pennsylvania and New York. Year 2000 U.S. Geological Survey true color aerial photographs (Hayes, 2002) were incorporated into the mapping software (Arc View 3.1; Esri, Redlands, CA). The ROVA sites were divided into $200 \times 200$-m grids and superimposed on Year 2000 high-resolution color aerial photographs of the six parcels (VAMA, FDR, ELRO, and Top Cottage) further divided into blocks (VAMABlock Al-HI0, etc.), and printed. Site-specific searches were conducted at two scales as single point-in-time observations: 1) the absence or presence of each species for each parcel property and 2) the location within each parcel such as landscape beds, cultivated flower gardens, stone walls, hedgerows, rocky outcrops, riparian areas, open fields, forest edges, dumps, and intermittent streams and ponds. The survey was conducted by extensively walking through each estate until all areas had been visually assessed for the presence of targeted species and detailed field notes recorded (Bravo, 2002). Because of time constraints, recently mowed meadows (formerly crop fields maintained by mowing), inaccessible areas of specific blocks, and the interior flower beds of the FDR, VAMA, and Bellefield public flower gardens that contain thousands of annual and perennial forbs were not inventoried or surveyed. Because more than 400,000 trees were planted on the FDR estate from 1911 to Roosevelt's death in 1945 (Auwaerter, 2009), some exotic silvicultural species were also excluded. Exotic species identifications were made using taxonomic keys (Fernald, 1989; Peterson and McKenny, 1974; Petrides, 1986; Rhoads and Block, 2000; University of Connecticut, 2002), voucher herbarium specimens, identification fact sheets (U.S. Department of Agriculture, 2002), and as needed verification by taxonomic experts familiar with the flora of the region.

Terms And Definitions. For this study, a clear distinction between cultivated and uncultivated exotic plants was made before conducting the survey and assessment based on historical records, FLORA list, herbarium list, and CLRs. Species' abundance within ROVA either in the cultivated or uncultivated landscape

\begin{tabular}{llll}
\hline $\begin{array}{l}\text { Units } \\
\begin{array}{l}\text { To convert U.S. to SI, } \\
\text { multiply by }\end{array}\end{array}$ & U.S. unit & SI unit & $\begin{array}{l}\text { To convert SI to U.S., } \\
\text { multiply by }\end{array}$ \\
\hline 0.4047 & acre(s) & ha & 2.4711 \\
0.3048 & $\mathrm{ft}$ & $\mathrm{m}$ & 3.2808 \\
1.6093 & mile(s) & $\mathrm{km}$ & 0.6214
\end{tabular}


were defined for the purpose of prioritization in the ROVA invasive species management plan as rare (few individuals only), infrequently occurring (not yet common), frequently occurring, common, and/or widespread throughout and not ranked if no data had been collected. Naturalized is defined as existing, reproducing, and thriving in multiple locations in minimally managed habitats away from cultivation and not associated with any prior cultivated plantings. Lastly, for the purpose of the ROVA invasive species management plan, an invasive plant species is defined as an exotic (and includes "North American native" plant species not native to the ROVA landscape) that has colonized a habitat outside of its historical planting and is reproducing and spreading rapidly or has migrated into ROVA by other means and is displacing native flora in natural resource areas and or is detrimental to the historical preservation of the cultural landscape.

\section{Results and discussion}

HistoriCAL RECORDS REVIEW. Review of available CLRs and other historical estate documents indicated that at least 147 (48\% of 308 species) of ROVA's flora were known to be exotic before the start of this study. The last CLRs inventory was reported for FDR by Claeys and Coffin (1995), for VAMA by Glenn (1998), and for ELRO by O'Donnell et al. (1992). The most recent natural resource vascular plant inventories were reported by Rudnicky (1984) and Dutton (1998). The 2002 cultural landscape inventory and natural resource area survey added 16 undocumented exotics to the ROVA flora database bringing the total number of known exotics in the history of ROVA to at least 163.

Cultural landscape and NATURAL RESOURCE AREA SURVEY RESULTS. The CLR's review provided a total of 170 species that were searched for in the cultural landscape. The introduction dates/decade for 102 species (96 exotics and 6 introduced natives) are shown in Table 1. The 102 species surveyed for in the cultural landscape, are best described as ornamentals (65), garden forbs (19), common weeds (8), crops (5), groundcovers (3), and aquatics (2). In all, $93 \%$ of the species listed in Table 1 were found in the cultural landscape survey. Although the CLRs provided information on another 68 species known to be present in ROVA at one point in time, they were not listed as invasive plants of concern on available (2002) invasive plant lists and as a means of targeting invasive species of most concern and relevancy to the NPS needs, they were excluded from the natural area assessment. Because of page constraints, 43 species listed on the available exotic plant lists that were surveyed for and not found described as aquatics (7), grasses (6), herbaceous plants (15), shrubs (3), trees (10), and woody/semi-woody vines (2) and the results for the 68 excluded species (surveyed for but not assessed) described as common weeds (38), crops (15), garden forbs (10), and ornamentals (5) are not included in this publication but are available upon request from the lead author as Appendix 1 and 2 , respectively.

Relevant to the estates' interpretive period timelines, at least 65 species shown in Table 1 have one or more specimens that were introduced (as plantings or referenced as weeds) during the preservation time periods (1900-62) and even some dating to 1799. In fact, there are several trees, shrubs, and woody vines at ROVA at least 90 years of age. Based on the stem girth and "mature" appearance of some of the larger specimens of chinese trumpetvine (Campsis grandiflora), oriental bittersweet (Celastrus orbiculatus), wintercreeper (Euonymus fortunei), english ivy (Hedera helix), 'Halleana' japanese honeysuckle [Lonicera japonica (a 3-inchdiameter vine was found at the VAMA estate)], virginia creeper (Parthenocissus quinquefolia), and 'Veitchii' boston ivy (Parthenocissus tricuspidata), it is possible some could be the same plantings that James L. Greenleaf, the original architect of the VAMA Italian gardens, specified in the 1903 "Plan No. 63: Diagrams of Plantings for East Half of Gardens" or that Thomas Meechan and Sons suggested in the "1910 Garden Plan prepared for F.W. Vanderbilt Esq., Hyde Park, NY" (Favretti and Rainey, 1988). In fact, of all the exotic species mentioned in the 1903 plan and 1910 plan, only three exotic clematis (Clematis sp.) and chinese pear (Pyrus pyrifolia) were not documented as having been actually planted and were also not found in cultivation in 2002 .

The most frequent landscape shrubs honeysuckle, mock orange, and burning bush found in the ROVA cultural landscapes have over the years included plantings of several different species and cultivars. There are at least three cultivars of the introduced orange-flowered trumpetvine (Campsis radicans) at ROVA-one scarlet or deep-red scraggly bush (perhaps 'Atropurpurea' or Crimson Trumpet'), the yellow 'Flava', and the introduced native orange-flowered vine. There are also at least two distinct cultivars of chocolate vine (Akebia quinata) at ROVA-one white and two purple flowering vines. Unfortunately, the available records used to conduct this study are not detailed enough to evaluate any invasive differences at the cultivar level for all species.

INVASIVE PLANT ASSESSMENT FINDINGS. Of the 102 (96 exotics and 6 introduced natives) introduced plant species, eight [three clematis species, chinese pear, bridalwreath spiraea (Spiraea prunifolia), thunberg's meadowsweet (Spiraea thunbergii), 'Regal' bukhara fleeceflower (Polygonum baldschuanicum), and carolina fanwort (Cabomba caroliniana)] are not currently propagated and were not found in the landscape survey. The bukhara fleeceflower was noted by Claeys and Coffin (1995) to be at least 50 years old in 1981 before its removal from ELRO. Vanhouttei spiraea (Spiraea $\times$ vanhouttei) is in cultivation at ROVA, but because of the presence of other similar native spiraeas in the natural resource areas, it was not assessed. All 90 species listed in Table 2 were assessed for the ROVA NHS invasive species management plan and are categorized in the assessment as "cultivated not escaped," "cultivated and escaped," or "not known from cultivation and found naturalized."

Cultivated nOt escaped. Thirty-six assessed species cultivated at ROVA (40\%), including one introduced native were classified as not invasive within ROVA (Table 2). They are best described as introduced groundcovers (2), introduced garden forbs (1), and the rest [33 (92\%)] were introduced as ornamentals. Ten exotic species in this category $(28 \%)$ were considered invasive or potentially invasive in the 2002 MAEPPC and NPS listings, and 17 exotic species in this category $(47 \%)$ are categorized as invasive in the $2010 \mathrm{New}$ 


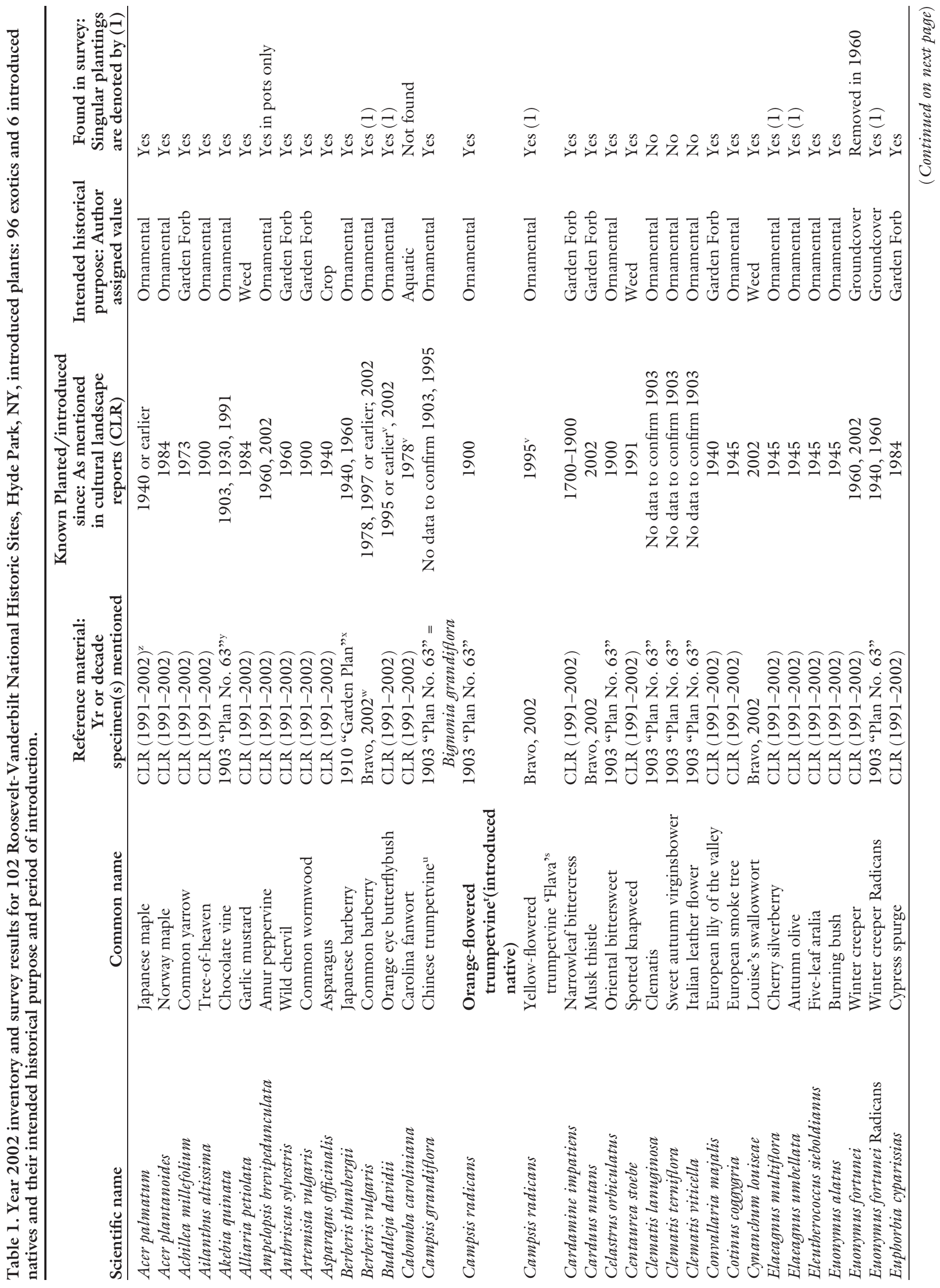

Hortlechnology • October 2012 22(5) 


\section{Public Horticulture}

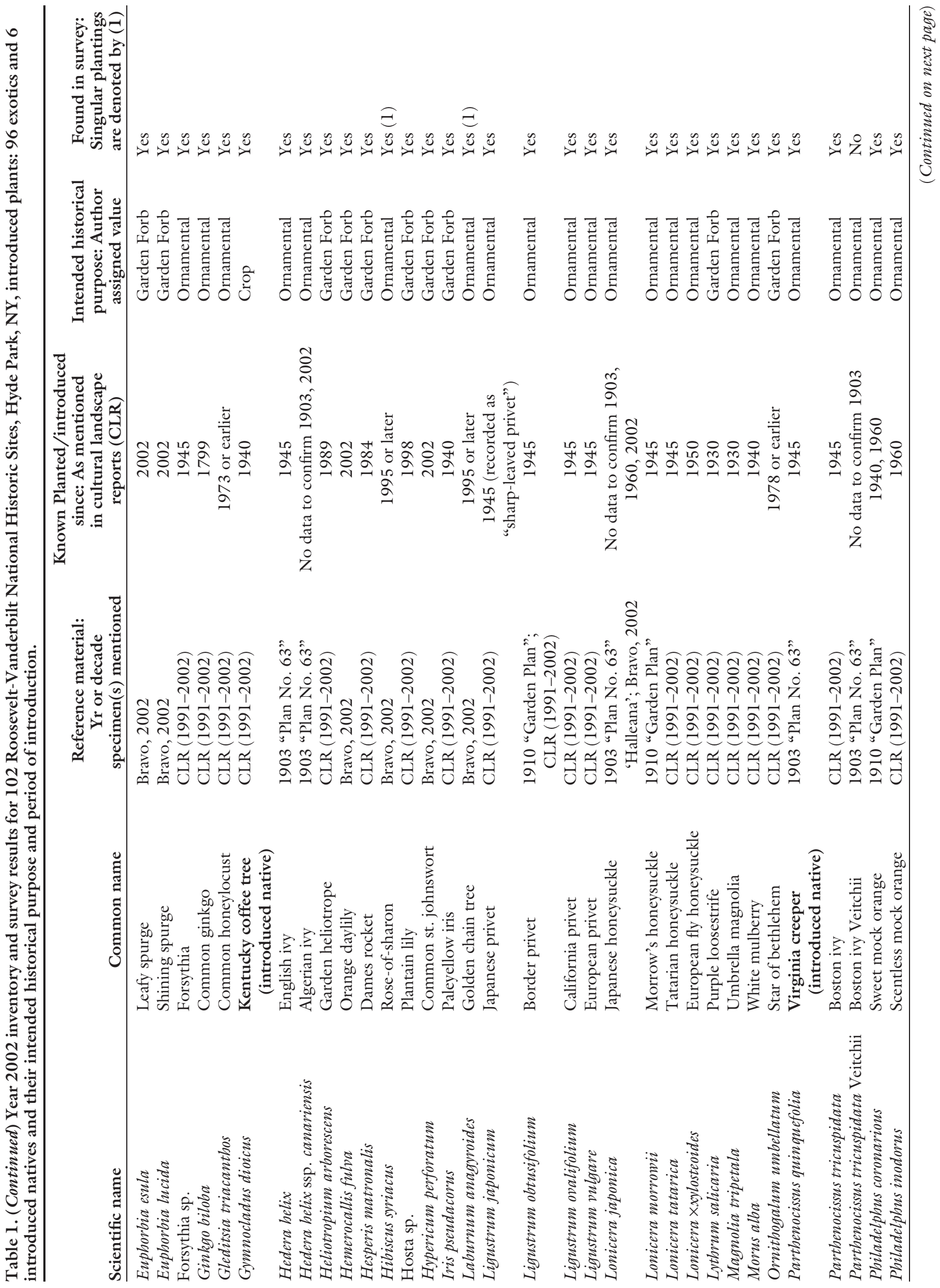




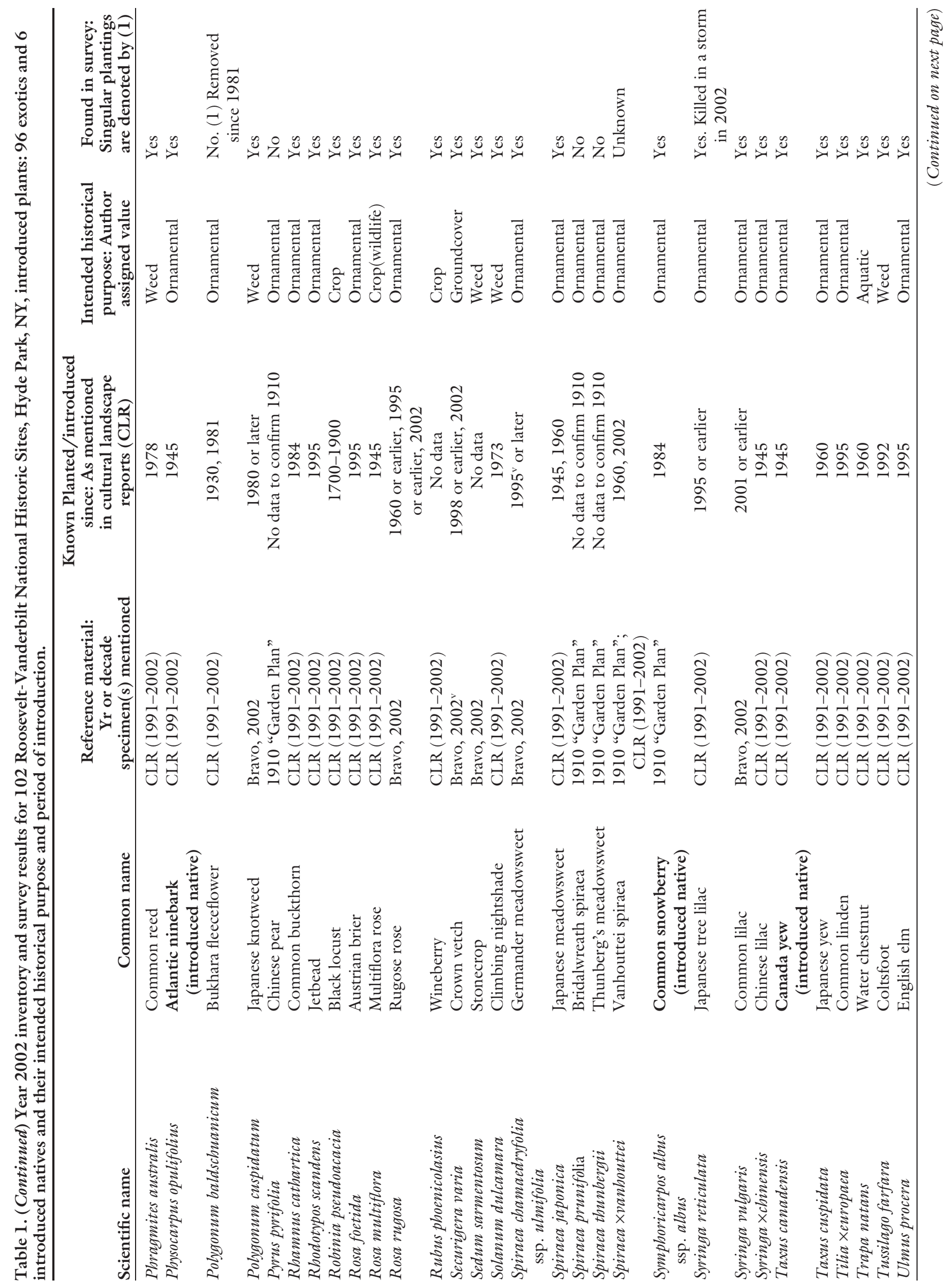




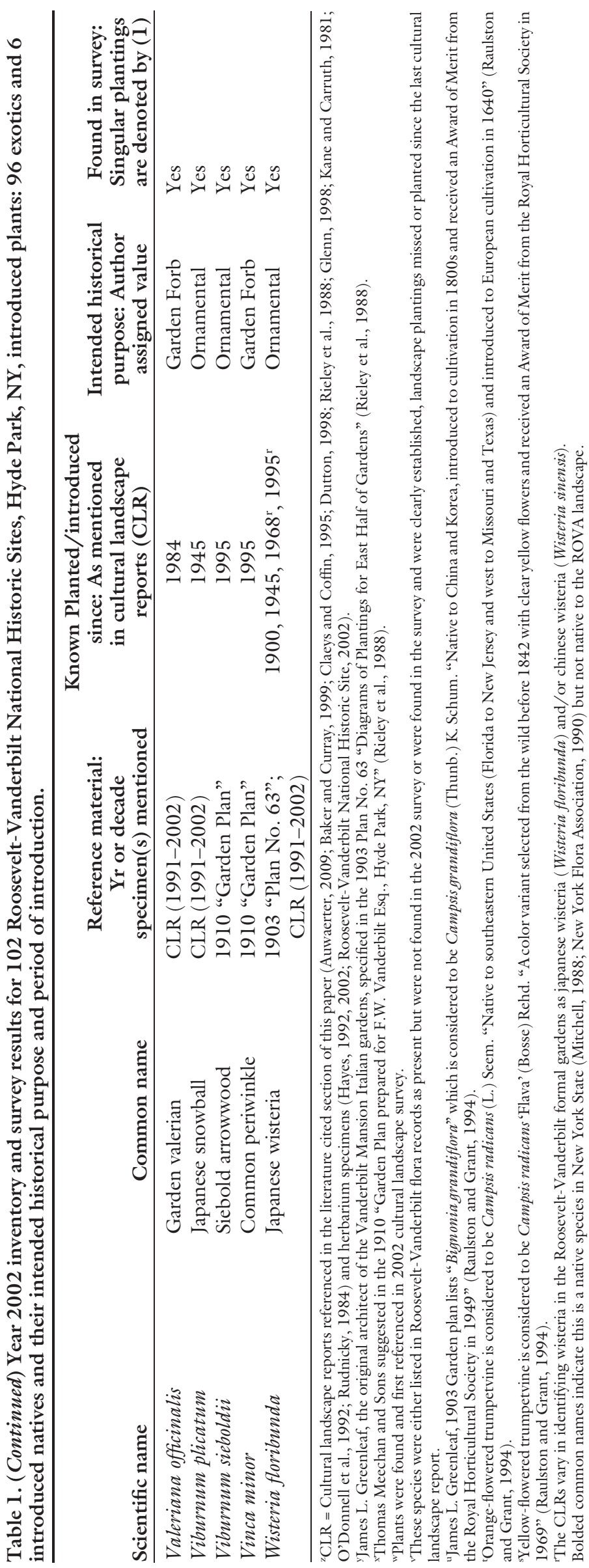

York rankings (Jordan et al., 2010). The vast majority of these exotics are rare or infrequently found in the cultural landscape and for this reason a few ambiguous detections were classified as not invasive now. For example, discarded clippings of chocolate vine were discovered in the compost dump at VAMA - there are only two old growth vines in the ROVA gardens and a 1991 restoration planting of this species elsewhere in ROVA. Other rarities such as common lilac (Syringa $\times$ vulgaris), privet (Ligustrum sp.), japanese spiraea, and the few locations of flower beds containing crown vetch (Securigera varia) were in the few instances of a detected escape, best described as abandoned plantings or discarded clippings and were not representative of the other cultural landscape plantings elsewhere in ROVA for the same species. However, the survey did reveal a lost planting (LP) of a five-leaf aralia (Eleutherococcus sieboldianus) on Bard Rock. The population was comprised of two to three primary shrubs surrounded by secondary shoots and sprouts numerous enough to form a dense thicket $10 \mathrm{ft}$ wide by $20 \mathrm{ft}$ long. The survey also revealed two juvenile shrubs of another five-leaf aralia planting sprouting adjacent to their regal looking mother plant at the FDR mansion. These shrubs demonstrated the same tendency for their canes to root as was observed for this species in the abandoned hedge on Bard Rock, a feature that was not observed in an old growth aralia bush at the ELRO estate. In 2002, very little information was available to determine if this species has invasive tendencies.

KNOWN FROM CULTIVATION AND ESCAPED. Forty species are present in the cultivated landscape of ROVA $(44 \%)$, and escapes of the same species were found in uncultivated areas or beyond the intended area of cultivation (Table 2). They are best described as introduced for wildlife (1), groundcover (1), crops (4), garden forbs (14), and the rest $[20(50 \%)]$ as ornamentals. In this category, 17 species $(43 \%)$ were considered invasive or potentially invasive in the 2002 listings and $21(53 \%)$ are ranked in the 2010 New York listing. Tree-of-heaven (Ailanthus altissima), the introduced native orange-flowered trumpetvine, oriental bittersweet, honeylocust (Gleditsia triacanthos), black locust 
Table 2. Year 2002 invasiveness assessment for 90 introduced plants currently found at the Roosevelt-Vanderbilt National Historic Sites, Hyde Park, NY: 84 exotics and six introduced native to New York State species and their abundance and invasive listing/ranking in available invasive plant lists.

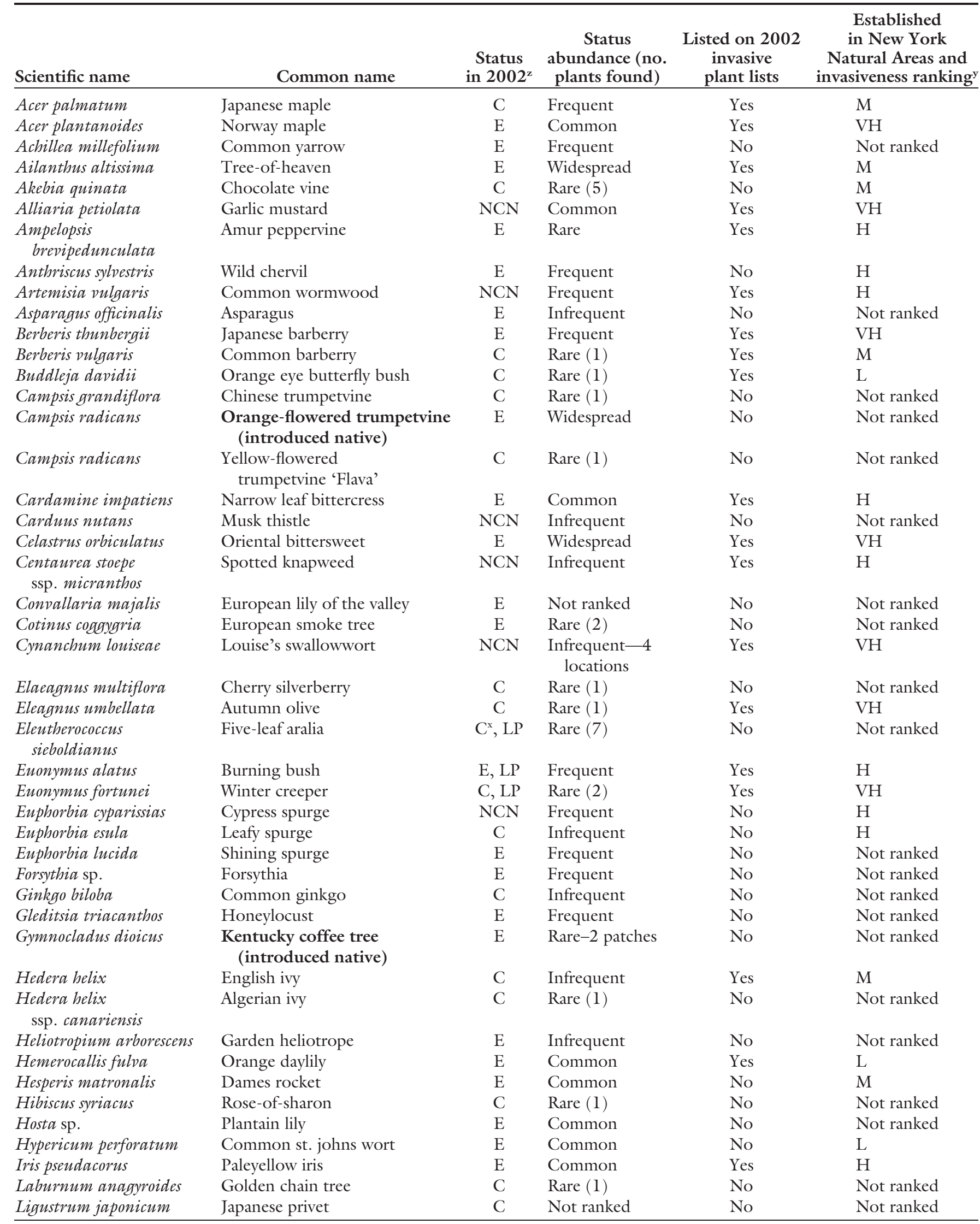


Table 2. (Continued) Year 2002 invasiveness assessment for 90 introduced plants currently found at the RooseveltVanderbilt National Historic Sites, Hyde Park, NY: 84 exotics and six introduced native to New York State species and their abundance and invasive listing/ranking in available invasive plant lists.

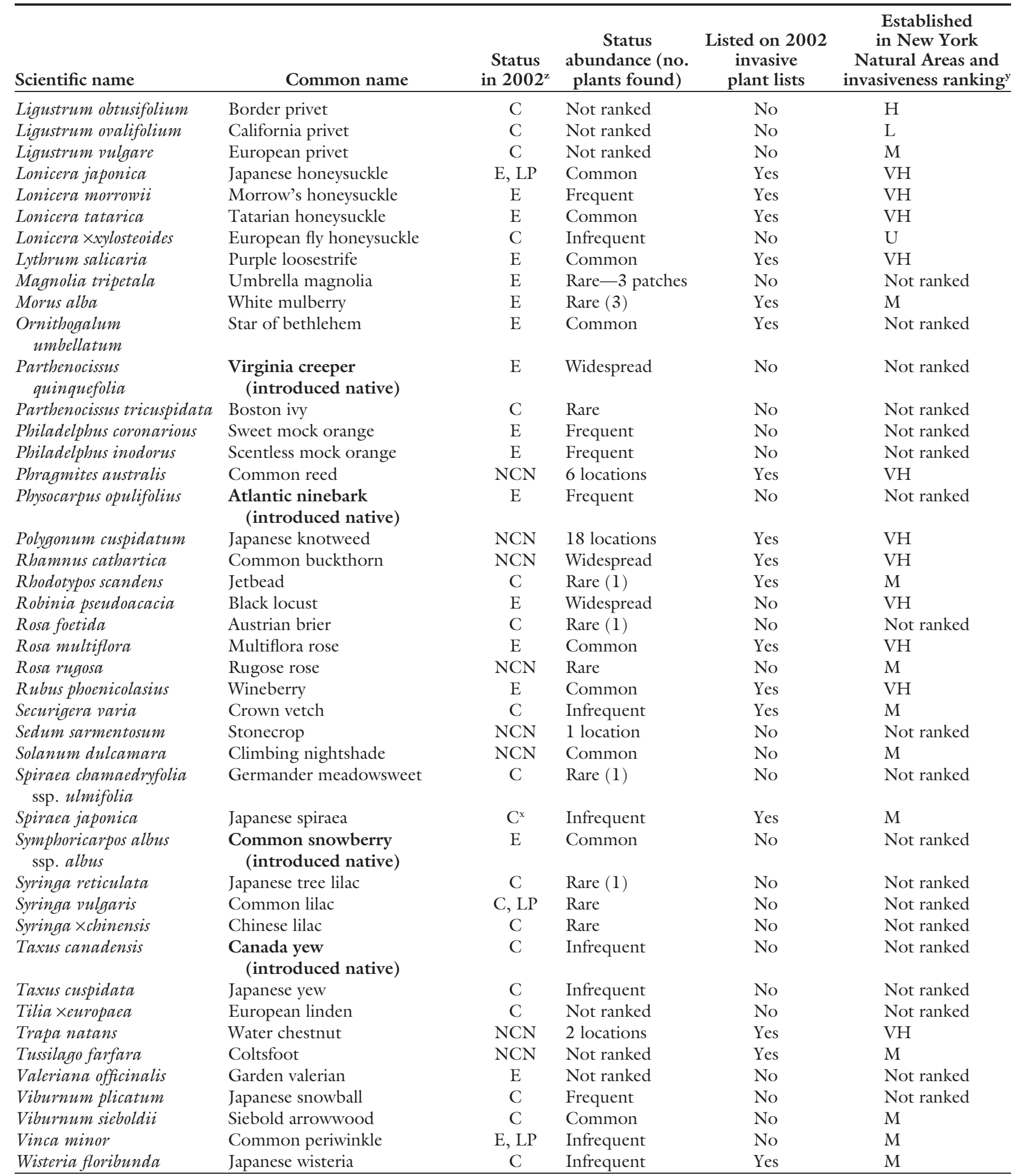

${ }^{2} \mathrm{C}=$ cultivated but not escaped $; \mathrm{E}=$ cultivated and escaped $; \mathrm{NCN}=$ not known from cultivation and found naturalized; $\mathrm{LP}=$ found and appears to be a lost planting from a long ago era and not ranked $=$ no data were collected to determine abundance.

yNew York State Invasiveness Ranks: $\mathrm{VH}=$ very high, $\mathrm{H}=$ high, $\mathrm{M}=$ moderate, $\mathrm{L}=$ low, $\mathrm{U}=$ unknown (insufficient information) (Jordan et al., 2010).

${ }^{x}$ For the Roosevelt-Vanderbilt National Historic Sites as a whole these were classified as cultivated. Within individual estates however a singular observation of an escape was noted.

Bolded common names indicate this is a native species in New York State (Mitchell, 1988; New York Flora Association, 1990) but not native to the ROVA landscape. 
Table 3. Select species present in the cultural landscape of the Roosevelt-Vanderbilt National Historic Sites, Hyde Park, NY, for at least 50-67 years if not longer at the Vanderbilt Mansion and Bark Rock (VAMA); Home of Franklin D. Roosevelt, Springwood Viewshed parcel and Bellefield estate (FDR); the Home of Eleanor Roosevelt and FDR's Top Cottage Retreat (ELRO).

\begin{tabular}{|c|c|c|c|c|}
\hline \multirow[b]{3}{*}{ Scientific name } & \multirow[b]{3}{*}{ Common name } & \multicolumn{3}{|c|}{ Cultivated $(C)^{\mathrm{z}}$ vs. cultivated escaped $(\mathrm{E})^{\mathrm{y}}$} \\
\hline & & $14(\mathrm{C})$ vs. $20(\mathrm{E})$ & $17(\mathrm{C})$ vs. $17(\mathrm{E})$ & $11(\mathrm{C})$ vs. $13(\mathrm{E})$ \\
\hline & & VAMA & FDR & ELRO \\
\hline Acer plantanoides & Norway maple & $\mathrm{E}$ & $\mathrm{E}$ & $\overline{\mathrm{E}}$ \\
\hline Ailanthus altissima & Tree-of-heaven & $\mathrm{E}$ & $\mathrm{E}$ & $\underline{E}$ \\
\hline Akebia quinata & Chocolate vine & $\mathrm{C}$ & $\mathrm{C}$ & 二 $^{x}$ \\
\hline Celastrus orbiculatus & Oriental bittersweet & $\mathrm{E}$ & $\mathrm{E}$ & $\underline{E}$ \\
\hline Cotinus coggygria & European smoke tree & $\underline{\mathrm{C}}$ & $\mathrm{E}$ & $\overline{\mathrm{C}}$ \\
\hline Eleutherococcus sieboldianus & Five-leaf aralia & $\overline{\mathrm{C}}$ & $\mathrm{E}$ & $\mathrm{C}$ \\
\hline Euonymus alatus & Burning bush & $\overline{\mathrm{E}}$ & $\underline{\mathrm{C}}$ & $\mathrm{E}$ \\
\hline Gymnocladus dioicus & $\begin{array}{l}\text { Kentucky coffee tree } \\
\quad \text { (introduced native) }\end{array}$ & $\mathrm{E}$ & $\mathrm{E}$ & $\underline{\mathrm{C}}$ \\
\hline Hedera belix & English ivy & $\mathrm{C}$ & $\mathrm{C}$ & $\underline{\mathrm{C}}$ \\
\hline Hedera belix ssp. canariensis & Algerian ivy & $\mathrm{C}$ & - & 二 \\
\hline Hibiscus syriacus & Rose-of-sharon & - & - & $\mathrm{C}$ \\
\hline Ligustrum japonicum & Japanese privet & $\mathrm{C}$ & - & - \\
\hline Ligustrum obtusifolium & Border privet & $\mathrm{E}$ & $\mathrm{C}$ & $\underline{\mathrm{C}}$ \\
\hline Ligustrum ovalifolium & California privet & - & $\mathrm{C}$ & 二 \\
\hline Ligustrum vulgare & European privet & $\mathrm{C}$ & $\mathrm{E}$ & - \\
\hline Lonicera japonica & Japanese honeysuckle & $\mathrm{E}$ & $\mathrm{E}$ & $\mathrm{E}$ \\
\hline Lonicera morrowii & Morrow's honeysuckle & $\mathrm{E}$ & $\mathrm{E}$ & 一 \\
\hline Rosa foetida & Austrian briar & - & $\mathrm{C}$ & 二 \\
\hline Rosa multiflora & Multiflora rose & $\mathrm{E}$ & $\mathrm{E}$ & $\mathrm{E}$ \\
\hline Spiraea chamaedryfolia ssp. ulmifolia & Germander spiraea & $\mathrm{C}$ & - & 一 \\
\hline Spiraea japonica & Japanese meadowsweet & $\underline{\mathrm{C}}$ & $\mathrm{C}$ & $\underline{E}$ \\
\hline Symphoricarpos albus ssp. albus & $\begin{array}{l}\text { Common snowberry } \\
\text { (introduced native) }\end{array}$ & $\overline{\mathrm{E}}$ & - & 二 \\
\hline Syringa reticulata & Japanese tree lilac & - & $\mathrm{C}$ & - \\
\hline Syringa $\times$ chinensis & Chinese lilac & - & $\mathrm{C}$ & - \\
\hline Taxus cuspidata & Japanese yew & $\underline{\mathrm{C}}$ & $\mathrm{C}$ & - \\
\hline Viburnum plicatum & Japanese snowball & 二 & $\mathrm{C}$ & $\underline{\mathrm{C}}$ \\
\hline Wisteria floribunda & Japanese wisteria & $\mathrm{C}$ & $\mathrm{C}$ & $\overline{\mathrm{C}}$ \\
\hline
\end{tabular}

${ }^{2}$ Cultivated not escaped. If underlined, this indicates the specimen was present in the cultural landscape and appeared to be of the age of similar 50 - to 67 -year-old specimens but the age of the planting was not recorded.

yescaped from cultivation. If underlined, this indicates the specimen was present in the cultural landscape and appeared to be of the age of similar 50 - to 67 -year-old specimens but the age of the planting was not recorded.

Specimen not present in the cultural landscape for this estate.

Bolded common names indicate this is a native species in New York State (Mitchell, 1988; New York Flora Association, 1990) but not native to the ROVA landscape.

(Robinia pseudoacacia), and the introduced native virginia creeper are widespread (Table 2) in the natural resource areas with introductions dating from 1900 to 1910 (Table 1). Burning bush, japanese barberry, morrow's honeysuckle, tatarian honeysuckle, sweet mock orange (Philadelphus coronarius), multiflora rose, and wine berry ( Rubus phoenicolasius) are infrequent to common invaders (depending on estate) of the ROVA natural resource areas 
(Table 2) with introductions dating from 1940 to 1945 (Table 1). While most are clearly escapes from cultivation and rampant (japanese barberry), quite a few old-growth shrubs can be classified as LPs such as the single, impressive, 6-ft-tall burning bush found at Bard Rock and another old growth shrub under the arched-bridge over Crum Elbow creek.

NOT KNOWN FROM CULTIVATION AND FOUND NATURALIZED. Fourteen exotic species $(16 \%)$ were not associated with past or present cultivation in the landscape or formal gardens (Table 2) and based on location are assumed to have migrated into the parcels from adjoining properties, the railroad, the Hudson River, or via adjacent roadways. These species are best described as common weeds (8), garden forbs (3), ornamentals (2), and aquatic (1). Common buckthorn (Rhamnus cathartica) and garlic mustard (Alliaria petiolata) are widespread in the natural resource areas and it would be difficult to eradicate these two invaders. The time line of introduction for louise's swallowwort (Cynanchum loniseae) and japanese knotweed (Polygonum cuspidatum) is documented in the ROVA flora and are considered recent invaders. There were no CLRs or other historical documentation to suggest that common buckthorn was ever planted in the cultural landscape. Also, it is not possible to determine if the garden forbs in this category were purposefully introduced at ROVA as plantings or were considered common weeds at the time referenced. Nine species in this category (NCN) were included on the regional exotic invasive plant lists and 12 species were included in the $2010 \mathrm{NY}$ ranking. It is important to note that in our study, $71 \%$ of the species excluded from the natural resource area invasive assessment (Appendix 2) could also be classified as common weeds or garden forbs but were for unknown reasons not listed as exotic plants of concern on the NPS and MAEEPC invasive plant lists. An invasive assessment of these species within ROVA was not determined in our 2002 study.

\section{Conclusions}

The intensity and extent of propagule pressure may be the single most important determinant of invasive plant establishment (Von Holle and Simberloff, 2005) and this is clearly evident within ROVA. The invasive assessment revealed that the most widespread naturalized families at ROVA are the trumpetvine, bittersweet, pea, buckthorn, quassia, and grape all of which are prolific seed producers. The invasion of woody shrubs into closed canopy forests of the mid-Atlantic region of the United States is well advanced (Ehrenfeld, 1997) and although not yet common, species (families) such as atlantic nine bark (Rosaceae), burning bush (Celastraceae), forsythia (Oleaceae), japanese barberry (Berbidaceae), mock orange species (Philadelphaceae), morrow's honeysuckle, and tatarian honeysuckle (Caprifoliaceae) are well on their way to becoming so in the ROVA natural resource areas. Daehler (1998) found plant families with the highest naturalization levels globally were the pea, grass, and aster families (Fabeaceae, Poaceae, and Asteraceae, respectively). Pemberton and Liu (2009) reported members of the arum, dogbane, mulberry, olive, spurge, and vervain families (Araceae, Apocynaceae, Moraceae, Oleaceae, Euphorbiaceae, and Verbenaceae, respectively) can be just as prevalent.

The contrasting results between these four studies emphasize the importance of specifying the landscape level (e.g., local, regional, national, or global) under consideration before interpreting and applying survey data and invasiveness assessment. That is because occurrences of escapes from cultivation vary by collection, by estate, by species, over time and one can infer, by management. By estate, and for the subset of assessed species found in cultivation for more than $\mathbf{5 0}$ years, slightly more species had escaped from cultivation at the VAMA and ELRO estates relative to non-escapes. However, at the FDR estate, the number of escaped vs. non-escaped species from cultivation was the same (Table 3 ). A comprehensive approach to evaluating the unique flora composition (crops, weeds, ornamentals, garden forbs, and aquatics) biodiversity, and nativity as well as a clear understanding of the historical significance and value of exotic trees, shrubs, and vines on display in the cultural landscape is recommended when developing future exotic plant inventories, surveys, and natural area assessments at historical sites. The species-specific results of this study by estate (Bravo, 2002) are being used by the ROVA NHS to implement its invasive species management plan for the natural resource areas within ROVA. The lead author (MAB) has used a similar "100 plus club," "50 plus club," "25 plus club," "10 plus club," and "five plus club" grouping of exotics of concern to assist the Pennsylvania Invasive Species Council and the general public in understanding the history of the purposeful (aquatic, crop, common weed, garden forb, or ornamental) or unintentional introduction (invader) of exotic plants into Pennsylvania.

\section{Literature cited}

Auwaerter, J. 2009. Cultural landscape report for Springwood, Home of Franklin D. Roosevelt National Historic Site, Hyde Park, NY, Vol. II: Treatment. Natl. Park Serv., Olmsted Ctr. Landscape Preservation, Boston, MA.

Baker, K. and G.W. Curray. 1999. Cultural landscape report for the Home of Franklin D. Roosevelt National Historic Site. Vol. 1: History, existing conditions, and analysis. Faculty Landscape Architecture, College Environ. Sci. For., State Univ. of New York, Syracuse.

Bravo, M.A. 2002. Invasive plant assessment and inventory of the RooseveltVanderbilt Natl. Historic Sites, Hyde Park, NY. Field notes for the Vanderbilt Mansion, Bard Rock, Home Of Franklin D. Roosevelt, Bellefield property, Springwood Viewshed parcel, Eleanor Roosevelt, and Franklin D. Roosevelt's Top Cottage retreat. Roosevelt-Vanderbilt Natl. Historic Sites, Hyde Park, NY.

Claeys, K. and M. Coffin. 1995. Historic plant inventory for the Bellefield Property, Home Of Franklin D. Roosevelt National Historic Site, Eleanor Roosevelt National Historic Site, Vanderbilt Mansion National Historic Site. Natl. Park Serv., Olmsted Ctr. Landscape Preservation in partnership with the Arnold Arboretum of Harvard Univ., Arnold Arboretum, Jamaica Plain, MA.

Daehler, C.D. 1998. The taxonomic distribution of invasive plants: Ecological insights and comparison to agricultural weeds. Biol. Conserv. 84:167-180.

Dewey, S.A. and K.A. Anderson. 2004. Distinct roles of surveys, inventories, and monitoring in adaptive weed management. Weed Technol. 18:14491452 . 
Dutton, E. 1998. Franklin D. Roosevelt National Historic Site vascular plant survey. Brooklyn Botanic Garden, New York.

Ehrenfeld, J.G. 1997. Invasion of deciduous forest preserves in the New York metropolitan region by japanese barberry (Berberis thunbergii DC.). J. Torrey Bot. Club 124:210-215.

Fernald, M.L. 1989. Gray's manual of botany. 8th (centennial) ed. Illustrated. A handbook of flowering plants and ferns of the central and northeastern United States and adjacent Canada. Disoscorides Press, Portland, OR.

Glenn, S.D. 1998. Vanderbilt Mansion National Historic Site vascular plant survey 1995-1997. Brooklyn Botanical Garden, New York.

Hayes, D. 1992. Roosevelt-Vanderbilt National Historic Sites flora list. RooseveltVanderbilt National Historic Sites, Hyde Park, NY.

Hayes, D. 2002. Invasive plant mapping index sheets for the home of Franklin D. Roosevelt, the Vanderbilt Mansion, and the home of Eleanor Roosevelt. 200-m grid aerial photography maps. RooseveltVanderbilt Natl. Historic Sites, Hyde Park, NY.

Jordan, M.J., G. Moore, and T.W. Weldy. 2010. Non-native plant species invasiveness assessment. 6 Mar. 2012. <http:// newyorkinvasivespecies.info/Resources / IS_Risk_Assessment.aspx $>$.

Kane, T.J. and P.C. Carruth. 1981. Comprehensive report on historic and cultural landscape. Eleanor Roosevelt National Historic Site, Hyde Park, NY. Kane and
Carruth Landscape Architects, Pleasantville, NY.

Mid-Atlantic Exotic Plant Pest Council. 2002. Invasive plant list. 18 Nov. 2011. <http://www.invasive.org/maweeds.cfm>.

Mitchell, R.S. (ed.). 1986. A checklist of New York State plants. Contributions of a flora of New York State. Bul. No. 458. New York State Museum, The Univ. of the State of New York, State Education Dept., Albany, NY.

National Park Service. 2002. Invasive plant list. Weeds gone wild: Alien plant invaders of natural areas. 18 Nov. 2011. <http://www.nps.gov/plants/alien/>.

New York Flora Association. 1990. Preliminary vouchered atlas of New York State flora, 1st ed. New York Museum Institute, Albany, NY.

O’Donnell, P.M., C.A. Birnbaum, and C. Zaitzevsky. 1992. Cultural landscape report for Vanderbilt Mansion National Historic Site. Vol. 1: Site history, existing conditions, and analysis. Natl. Park Serv., North Atlantic Reg., Div. Cultural Resources Mgt., Cultural Landscape Program, Boston, MA.

Pemberton, R. and H. Liu. 2009. Marketing time predicts naturalization of horticultural plants. Ecology 90:69-80.

Peterson, R.A. and M. McKenny. 1974. A field guide to wildflowers. Northeastern and north-central North America. 2nd ed. Houghton Mifflin, Boston, MA.

Petrides, G.A. 1986. A field guide to trees and shrubs. Northeastern and northcentral United States and southeastern and south-central Canada. 2nd ed. Houghton Mifflin, Boston, MA.
Raulston, J.C. and G. Grant. 1994. Trumpetvines (Campsis) for landscape use. Proc. Southern Nursery Assn. Res. Conf. 39: 359-363.

Rhoads, A.F. and T.A. Block. 2000. The plants of Pennsylvania. An illustrated manual. Morris Arboretum of the University of Pennsylvania. University of Pennsylvania Press, Philadelphia, PA.

Rieley, W., R.J. Favretti, and R.M. Rainey (Rieley Associates). 1988. Cultural landscape report. Vanderbilt Mansion $\mathrm{Na}-$ tional Park Service. Rieley Assoc., Charlottesville, VA.

Roosevelt-Vanderbilt National Historic Sites. 2002. Herbarium collection. Rath Collection Storage Building, Home of Franklin D. Roosevelt Natl. Historic Site, Hyde Park, NY.

Rudnicky, J.L. 1984. Natural resource inventory of the Vanderbilt Mansion $\mathrm{Na}$ tional Historic Site, Hyde Park, NY. U.S. Dept. Interior, Natl. Park Serv. North Atlantic Region, Office Scientific Studies, Boston, MA

U.S. Department of Agriculture. 2002. The PLANTS database. 5 Mar. 2010. $<$ http://plants.usda.gov>.

University of Connecticut. 2002. Invasive plant atlas of New England. Herbarium records. George Safford Torrey Herbarium, Univ. Connecticut, Storrs.

Von Holle, B. and D. Simberloff. 2005. Ecological resistance to invasion overwhelmed by propagule pressure. Ecology 86:3212-3218. 